\title{
Lysine-Specific Demethylase 5C
}

National Cancer Institute

\section{Source}

National Cancer Institute. Lysine-Specific Demethylase 5C. NCI Thesaurus. Code C97600.

Lysine-specific demethylase 5C (1560 aa, $176 \mathrm{kDa}$ ) is encoded by the human KDM5C

gene. This protein is involved in both chromatin modification and transcriptional

modulation. 